\title{
Grown-Up Income Shifting: Yesterday's Kiddie Tax Is Not Enough
}

\author{
Samuel D. Brunson* \\ I. INTRODUCTION
}

As part of its ongoing war against tax evasion, Congress changed the tax law in 1986 to make income shifting ${ }^{1}$ less viable and less attractive. ${ }^{2}$ Congress assaulted income shifting on two fronts. First, it passed provisions that closed perceived loopholes in the tax law that permitted income shifting. Second, it passed provisions that, while not aimed directly at income shifting, resulted in its being less attractive.

In the latter category were the changes to tax brackets made by the Tax Reform Act of 1986 (the Act). ${ }^{3}$ The Act reduced both the number of tax brackets and their rates. Before the Act, there were fourteen tax brackets; after the Act, there were just two. ${ }^{4}$ At the same time, the Act reduced the highest marginal rate from fifty percent to twenty-eight percent. ${ }^{5}$ This compression of tax brackets, combined with the reduction in marginal rates, significantly decreased the amount by which income shifting could reduce a taxpayer's tax liability.

Congress's principal direct assault on income shifting sought to prevent wealthy parents from unfairly reducing their tax bills by giving some of their dividend-paying stocks and interest-bearing bonds to their

\footnotetext{
* Assistant Professor, Loyola University Chicago School of Law. Thanks to Heather M. Field, Stephanie McMahon, Jeffrey Kwall, Spencer Waller, and Sacha Coupet for their helpful suggestions and comments on earlier drafts of this Article.

1. For purposes of this Article, "income shifting" refers to the practice of a high-income taxpayer giving assets to a lower-income taxpayer so that either income produced by the asset or capital gains on the sale of the asset will be taxed to the recipient at her lower rate.

2. See Frederick R. Schneider, Which Tax Unit for the Federal Income Tax?, 20 U. DAYTON L. REV. 93, 103 (1994).

3. See Alan J. Auerbach \& Joel Slemrod, The Economic Effects of the Tax Reform Act of 1986, 35 J. ECON. LITERATURE 589, 598 (1997) (“The reform included a number of provisions designed to prevent corporations and higher-income individuals from using certain tax-avoidance strategies to pay little or no tax.”).

4. Schneider, supra note 2, at 103.

5. John W. Lee, III, The Capital Gains "Sieve" and the "Farce" of Progressivity 1921-1986, 1 HASTINGS Bus. L.J. 1, 6 (2005).
} 
children. ${ }^{6}$ To stop this tax-motivated income shifting, Congress enacted the "kiddie tax."7 Congress believed that income deflected to children continued to benefit the children's parents. ${ }^{8}$ In Congress's view, the deflected income either continued under the control of the parents, albeit indirectly, ${ }^{9}$ or reduced the expenses that parents otherwise would have had to bear. ${ }^{10}$ To combat this abuse, the kiddie tax taxed any passive income earned by a child under the age of fourteen at her parents' marginal tax rate. ${ }^{11}$ By increasing the rate of tax on children's passive income, the kiddie tax succeeded in significantly reducing the advantages of shifting income to children. ${ }^{12}$

Since its passage, there has been little consideration of the effectiveness of the kiddie tax, much less the policies underlying the choice of the kiddie tax to defend against income shifting. An initial colloquy of two articles published shortly after the enactment of the kiddie tax discussed the kiddie tax's purpose and alterations that could make it more effective. ${ }^{13}$ Subsequently, the occasional article has examined the kiddie tax in light of the problem of income shifting ${ }^{14}$ or discussed how to comply with or plan around the higher rates imposed by the kiddie tax. ${ }^{15}$ But no discussion has emerged on whether the kiddie

6. See S. REP. No. 99-313, at 862 (1986) (“[T]he committee is aware that the treatment of a child as a separate taxpayer encourages parents whose income would otherwise be taxed at a high marginal rate bracket to transfer income-producing property to a child to ensure that the income is taxed at the child's lower marginal rates.”).

7. See Victor Thuronyi, The Kiddie Tax: A Reply to Professor Schmolka, 43 TAx L. REV. 589, 589-90 (1988). In addition to the kiddie tax, Congress made it more difficult for wealthy taxpayers to shift their tax burden by transferring property to a trust. See Schneider, supra note 2, at 105-06. The trust provisions are beyond the scope of this Article.

8. See Thuronyi, supra note 7, at 590.

9. See id.

10. See S. REP. No. 99-313, at 862.

11. Leo L. Schmolka, The Kiddie Tax Under the Tax Reform Act of 1986: A Need for Reform While the Ink Is Still Wet, 11 REv. TAX'N InDividuALS 99, 101-02 (1987). Currently, the kiddie tax applies to children who are younger than eighteen or, in the case of a student whose earned income does not exceed half of the amount of her support, twenty-four. See I.R.C. § 1(g)(2)(A) (Supp. II 2009).

12. See Schneider, supra note 2, at 105 ("Thus, only a comparatively small amount of the child's income will be taxed at a rate lower than the parent's rate, significantly reducing the incentive to shift income to a child who is less than fourteen years of age.").

13. See generally Schmolka, supra note 11 (examining the kiddie tax and arguing that it should be replaced with a more effective and less complicated alternative); Thuronyi, supra note 7 (responding to Professor Schmolka's article and defending the kiddie tax).

14. See generally Richard C.E. Beck, The Kiddie Tax: A Nuisance Solution to a Nonexistent Problem, 30 FAM. L.Q. 103 (1996) (arguing that the kiddie tax should be repealed because it is poorly conceived and because income shifting is a nonexistent problem).

15. See, e.g., Leonard J. Lauricella, The New Kiddie Tax: Tax Planning with Acceleration and Deferral, 117 TAX NoTES 1235, 1235 (2007) (discussing how certain children may generate losses 
tax successfully prevents the tax-motivated income shifting Congress attempted to prevent through its enactment, what unintended consequences result from the kiddie tax, whether the kiddie tax represents good tax policy, or whether a more effective way to prevent income shifting exists.

In the quarter century since the kiddie tax was first enacted, the number of tax brackets has multiplied and marginal tax rates have increased. From the two tax brackets created by the Act in 1986, the Internal Revenue Code now has five. ${ }^{16}$ And the highest marginal rate has risen from twenty-eight percent to a current thirty-five percent ${ }^{17}$ and is currently scheduled to rise to $39.6 \%$ in $2013 .{ }^{18}$ As the indirect pressure on income shifting has waned, the potential tax savings associated with income shifting have increased, leaving the kiddie tax to ameliorate income shifting to children in a world where such income shifting will look progressively more attractive.

To effectively protect tax revenue, the kiddie tax needs to grow up. This Article will analyze whether the kiddie tax represents good tax policy and will analyze how well the kiddie tax succeeds at its raison d'être-preventing parents and grandparents from reducing their tax burdens by shifting assets to their lower-taxed descendents. Finding the kiddie tax wanting in both of these areas, the Article will then propose that Congress rework the kiddie tax to make it effective in the increasingly progressive tax climate of the twenty-first century.

The Article will proceed as follows: Part II will briefly discuss the impetus and difficulties in designing tax provisions that are intended to prevent abuse, rather than simply to raise revenue. Part III will review why the kiddie tax came into existence and how it works to discourage

in one year to avoid kiddie tax liability in the subsequent year). That the bulk of articles written on the kiddie tax address how to avoid it or lessen its effects makes it appear that the kiddie tax is ineffective in raising revenue. Rather, the kiddie tax creates waste in the system: children pay money - for tax and investment advice and administrative costs in structuring their investments- to avoid the kiddie tax, instead of using the money as they would prefer to use it. This additional money does not all serve to increase the government's revenue. That portion that is lost to administrative expenses is waste. See Samuel D. Brunson, Elective Taxation of Risk-Based Financial Instruments: A Proposal, 8 Hous. BUS. \& TAX L.J. 1, 10-11 (2007) ("This economic waste, measured in money and time spent avoiding taxes, could be better spent in socially and economically productive ways.”).

16. See I.R.C. § 1(a)-(e) (2006).

17. Id. $\S 1(\mathrm{i})(2)$.

18. See Tax Relief, Unemployment Insurance Reauthorization, and Job Creation Act of 2010, Pub. L. No. 111-312, § 101(a), 124 Stat. 3296, 3298. In addition, the tax rate on dividend income would also increase from the current long-term capital-gain rate of fifteen percent to ordinary rates of up to 39.6\%. See Katherine Pratt, Deficits and the Dividend Tax Cut: Tax Policy as the Handmaiden of Budget Policy, 41 GA. L. REV. 503, 505-06 \& n.7 (2007). 
high-income adults from shifting income-producing assets to children. Part IV will summarize major arguments surrounding the treatment of spouses as an economic unit for tax purposes. It will then apply the same analysis to including children in the economic unit.

Part V will evaluate whether the kiddie tax has accomplished its purposes, as well as its unintended consequences for children. Part VI discusses the small changes to the kiddie tax that have been made or proposed and examines why such incremental reform (1) will never create an anti-abuse regime that robustly prevents the income shifting that the kiddie tax was enacted to prevent and (2) will fail to reign in the overbreadth from which the current kiddie tax suffers.

Finally, Part VII proposes that Congress replace the current kiddie tax with a grown-up kiddie tax. The grown-up kiddie tax would keep the same general outline of the current kiddie tax-it would continue to tax certain income earned by a child at her parents' marginal rate-but would otherwise be entirely rethought. Instead of bifurcating a child's income between earned and unearned, like the current kiddie tax does, the grown-up kiddie tax would divide it into income from assets received as gifts and other income. By redesigning the kiddie tax in this way, the tax law would discourage income shifting without penalizing a child's savings and investment.

\section{DifFiculties In Designing TARgeted Anti-Abuse TAX PROVISIONS}

A good tax system avoids interfering with taxpayers' economic decision-making insofar as it is able. ${ }^{19}$ To the extent that tax considerations change what a taxpayer would have done in a tax-free world, a tax system creates waste by causing the taxpayer to expend money on planning and compliance and by preventing the taxpayer from allocating her economic resources in the most productive manner. ${ }^{20}$

However, distortions are inherent in an income tax. The mere imposition of an income tax will, for example, cause a taxpayer to spend

19. Yoram Margalioth, Student Paper, The Case for Tax Indexation of Debt, 15 AM. J. TAX POL’y 205, 254 (1998) (“The standards for a good tax system are its efficiency and its fairness. By the term efficiency we generally mean minimal interference with economic behavior to allow the allocation of economic resources to their most productive uses.").

20. See Richard A. Epstein, Taxation in a Lockean World, in PhiLOsophy AND LAW 49, 56 (Jules Coleman \& Ellen Frankel Paul eds., 1987) (“A sound tax ... will always be subject to some evasive response by private parties. But these are minimized by a system that does not seek to reshape basic preferences....”). 
money on compliance and other administrative costs related to determining and paying the tax, even though, absent the tax, she would not have incurred those administrative costs. ${ }^{21}$ Moreover, the existence of an income tax encourages taxpayers to choose leisure rather than work and consumption rather than saving, even if, absent tax considerations, they would rather work and save. ${ }^{22}$

The very abuse that prompted Congress to enact the kiddie tax-the transfer of income-producing assets from a higher-taxed parent to a lower-taxed child ${ }^{23}$-is the result of distortions caused by our progressive income tax system. If there were no difference between the rate of tax paid by the parent and the rate of tax paid by her child, the parent would only transfer income-producing assets to her child if she had a nontax reason to prefer that the assets be held by her child. ${ }^{24}$ Taxes would not create a financial impetus for her to do so.

Congress decided that it would tax a child's passive income at her parents' rate to counteract the distortions inherent in a progressive tax. ${ }^{25}$ By raising the child's tax rate to that of her parents, the kiddie tax eliminates the tax advantage of giving income-producing property to a child. However, the kiddie tax is a blunt instrument by which to solve the distortions that encourage income shifting, one that produces distortions of its own. Rather than merely eliminating the tax-based incentive to shift income-producing assets, the kiddie tax-by imposing a higher tax and administrative expenses to comply with its rulesdiscourages all transfers of income-producing property, even those that are not tax-motivated. That is, it treats a transfer from a parent, who may maintain indirect control over the assets-even when putatively owned by her child-and would therefore benefit from the imposition of a lower rate of tax on the asset, ${ }^{26}$ the same as it treats the transfer of property

21. See id. ("Any tax system costs money to administer.... The smaller their sum, the greater the fraction of the social product that is left for use in either public or private hands.... If the costs of collection are high, it increases the likelihood that the taxation ... will not meet the requirements of a proper Pareto-superior forced exchange.”).

22. Margalioth, supra note 19, at 254-55 ("The imposition of tax will always have some distorting effects, such as the allocation of resources to administrative costs of complying and collecting the tax, the encouragement of leisure over work and consumption over saving, but a good tax system will keep these distortions minimal.”).

23. See S. ReP. No. 99-313, at 862 (1986).

24. See Henry J. Lischer, Jr., Incomplete Transfer Tax Repeal: Should the Gift Tax Survive?, 56 SMU L. REV. 601, 619 (2003) ("As a preliminary matter, it should be noted that income shifting of built-in gain is worthwhile only if the transfer causes the income or gain to be taxed a lesser effective rate of tax than it would in the hands of the transferor.").

25. See id.

26. Note that although it is possible that a parent will maintain control over an asset even after 
from a family friend, who maintains no continuing control over the asset and receives no benefit from its being taxed at a lower marginal rate. ${ }^{27}$

Such an overcorrection, though inefficient, is understandable. After all, any tax provision can create distortions, and it may be difficult to calibrate reform so that it neither over nor undercorrects the targeted distortion. ${ }^{28}$ But the kiddie tax does not merely overcorrect a distortion. Rather, it introduces a new and unrelated distortion-it discourages saving and investment by the child. ${ }^{29}$ Any income tax encourages consumption over saving and investment to some extent by lowering the rate of return on saved and invested money in relation to what it would have been in a world without tax. ${ }^{30}$ This broad discouragement of saving and investment by children is unrelated to the transfer of incomeproducing assets to children. It applies whether the passive income is paid by an asset that was given to the child-either by a parent or anyone else-or whether the child invested her own wage income. Moreover, it does not just apply to risky or unusual investment practices. The kiddie tax is imposed on interest earned by a child on a plain-vanilla savings account at any commercial bank. ${ }^{31}$ And now that the kiddie tax potentially applies to people up to the age of twenty-three, ${ }^{32}$ its additional distortions are likely to reach income well beyond the scope of the kiddie tax's original mandate.

\section{HOW THE KIDDIE TAX WORKS}

Under the U.S. tax system, income derived from property is almost always taxed to the owner of the property. ${ }^{33}$ When income from property

transferring it to her child, it is not always the case that she will maintain such control. See infra notes 108-13 and accompanying text.

27. That the family friend gets no benefit from her asset being taxed at a lower rate is not entirely true in every circumstance. If the family friend were a tax protestor who felt warm and fuzzy when she kept money from getting into the hands of the government, she would benefit from transferring the property. But this type of warm fuzzy feeling is similar to the benefit that somebody gets in general from giving a gift; it is difficult to quantify economically, and, for that reason, giftgivers are not taxed on the benefit they get from giving a gift.

28. See Epstein, supra note 20, at 56 ("Taxes can create distortions that reduce wealth. The question is how to minimize these distortions.”).

29. See infra Part V.A.

30. See Margalioth, supra note 19 , at 254 \& n.164.

31. See I.R.C. $\S \S 1(g)(4), 911(d)(2)$ (2006). Because unearned income includes all of a child's income except wages, salaries, professional fees, and other amounts received as compensation for services performed, even income as innocuous as the interest on a savings account is potentially subject to taxation at the parents' higher rate. See id.

32. See id. § 1(g)(2)(A)(ii) (Supp. II 2009).

33. Schmolka, supra note 11 , at 100 ; see also Jonathan G. Blattmachr, Child's Income May Be 
is taxed to somebody other than the owner of the property, it is generally because Congress or a court has stepped in to prevent what it views as income shifting, where the incidence of the tax falls on a person taxed at a lower rate than the person who principally benefits from the income. ${ }^{34}$ That is, the default rule taxing income from property to the owner of the property generally applies unless a court, the IRS, or Congress feels that taxpayers are engaging in abusive transactions to shift their tax burdens to somebody who will be taxed on the income at a lower rate. ${ }^{35}$

Even when Congress believes abuse is present, however, it does not always shift the tax liability from the recipient of the money to the actual beneficiary. The kiddie tax is a prime example. Congress was concerned that parents and grandparents were avoiding taxes by transferring income-producing assets to their minor children or grandchildren. $^{36}$ Because children are generally taxed at a lower marginal rate than adults, the income would be taxable at the child's lower rate rather than the adult's higher rate. ${ }^{37}$ If the adult transferor arguably continues to maintain control over the asset because of her influence over her child, ${ }^{38}$ transferring income-producing assets to one's child would seem an ideal way for a high-income taxpayer to reduce her tax liability.

Rather than taxing parents on the passive income generated by transferred property, though, the kiddie tax treats the child as the appropriate taxpayer. ${ }^{39}$ To negate the tax advantages of income shifting, the kiddie tax changes the rate applicable to a child's passive income. ${ }^{40}$ The rough result of the kiddie tax is to tax a child at her parents' highest marginal tax rate on all of the child's unearned income. ${ }^{41}$

As originally proposed, the kiddie tax would have only applied to a child's unearned income attributable to property transferred to her by her

Taxed at Parent's Tax Rate, 66 J. TAX’N 48, 48 (1987) (“Generally, before 1987, unless a special rule applied, each taxpayer was taxed on his or her own income ... starting with the lowest effective rate in effect for that taxpayer.”).

34. See Blattmachr, supra note 33, at 48.

35. See id.

36. See Schmolka, supra note 11, at 101 ("Congress decided that a statutory remedy was needed to curb the potential for tax avoidance through intrafamily transfers of income-producing property.”).

37. See id. at 100.

38. See Thuronyi, supra note 7, at 590 ("Even if the property is transferred to the children on paper, in reality, the parents may still retain dominion over the property that they enjoyed when it was nominally in their names.”).

39. See Schmolka, supra note 11, at 101-02.

40. See I.R.C. § 1(g)(1) (2006).

41. Blattmachr, supra note 33, at 48. 
parent or step-parent. ${ }^{42}$ The Conference Committee broadened the kiddie tax, however, so that it applied to virtually all unearned income received by a child, whatever the source of the property from which the child receives the income. ${ }^{43}$

The kiddie tax governs a child's tax liability until she ages out of the kiddie tax if, at the end of the year, at least one of her parents is still alive, and she does not file a joint return for the year. ${ }^{44}$ In its original form, a child would age out of the kiddie tax the year she turned fourteen. ${ }^{45}$ In 2005, Congress raised the age from fourteen to eighteen. ${ }^{46}$ In 2007, Congress again raised the maximum age at which the kiddie tax applies to a child. ${ }^{47}$ Under current law, a child may age out of the kiddie tax in three possible years, depending on her circumstances. At the earliest, she will no longer be subject to the kiddie tax for the taxable year in which she turns eighteen, provided her earned income constitutes more than half of her support for the year. ${ }^{48}$ If her earned income is half or less of her support, she may age out of the kiddie tax in the year she turns nineteen, unless she is a student. ${ }^{49}$ If she is a student, though, and her earned income constitutes half or less of her support for the year, the kiddie tax continues to apply until the year in which she turns twentyfour. ${ }^{50}$

The Joint Committee on Taxation estimated that the kiddie tax would produce revenue of $\$ 1.004$ billion for the government between 1987 and 1991, rising from $\$ 60$ million raised in 1987 to $\$ 195$ million in 1988,

42. See S. REP. NO. 99-313, at 862 (1986) ("In order to reduce the opportunities for tax avoidance through intra-family transfers of income producing property, the committee concluded that it is generally appropriate to tax the income on property transferred from a parent to a minor child at the parent's marginal rates.”).

43. Blattmachr, supra note 33, at 48 ("[T]he Conference Committee elected to have virtually all unearned income taxed to the child at the parents' marginal rates of taxation.”).

44. See I.R.C. § 1(g)(2) (Supp. II 2009).

45. When originally enacted, Congress chose not to apply the kiddie tax to children aged fourteen and over because it assumed that a significant number of such children might have enough earned and unearned income to make the operation of the kiddie tax complicated. See Thuronyi, supra note 7, at 599 ("[T] he assumption was made that a number of children above age 14 might have substantial earned income and accordingly would have substantially more complicated financial situations than, say, the typical three-year-old.”).

46. Tax Increase Prevention and Reconciliation Act of 2005, Pub. L. No. 109-222, § 510(a), 120 Stat. 345, 364 (codified as amended at I.R.C. § 1(g)(2)(A)).

47. See Small Business and Work Opportunity Tax Act of 2007, Pub. L. No. 110-28, § 8241(a), 121 Stat. 190, 199 (codified as amended at I.R.C. § 1(g)(2)(A)).

48. See I.R.C. § $1(\mathrm{~g})(2)(\mathrm{A})(\mathrm{i})$.

49. See id. § 1(g)(2)(A)(ii); § 152(c)(3)(A) (2006 \& Supp. II 2009).

50. See id. The inclusion of twenty-three-year-olds in the kiddie tax suggests that, in its current incarnation, "kiddie tax" is a misnomer. 
\$226 million in 1989, \$249 million in 1990, and \$274 million in 1991..$^{51}$ In 1988, IRS data indicated that approximately 274,000 children were required to file a Form 8615 with the IRS because of the kiddie tax. ${ }^{52}$ Of those 274,000 children subject to the kiddie tax, over ninety percent had income for the year of less than $\$ 5000 .^{53}$

By 2005, the number of children required to file Form 8615 had fallen to $142,000 .^{54}$ But in 2006, as a result of increasing the age cutoff from fourteen to eighteen, the number of children subject to the kiddie tax more than doubled to $331,000 .^{55}$ Additionally, the kiddie tax paid more than doubled in 2006 to $\$ 645.2$ million. ${ }^{56}$

If the kiddie tax applies to a child, she must determine her tax liability under two parallel regimes: she must calculate both the amount of tax she would owe if she were not subject to the kiddie tax and the amount she would owe applying the kiddie tax. ${ }^{57}$ She then must pay the higher of the two amounts. ${ }^{58}$

To determine what she owes under the kiddie tax, a child must determine her "net unearned income," which is the amount of her adjusted gross income that is not attributable to her wages, salaries, professional fees, and other compensation for services rendered. ${ }^{59}$ Her net unearned income is further reduced by an inflation-adjusted threshold amount. $^{60}$ All passive income-including interest, dividends, and capital

51. Joint Comm. on TAXation, 99Th Cong., General Explanation of the TAX Reform ACT OF 1986, at 1255 (Joint Comm. Print 1987).

52. Michael E. Weber \& Laura Y. Prizzi, Individual Income Tax Returns for 1988: Selected Characteristics from the Taxpayer Usage Study, SOI BuLL., Fall 1989, at 11, 25 tbl.9.

53. See id.

54. See Brian Balkovic, Individual Income Tax Returns, Preliminary Data, 2006, SOI Bull., Spring 2008, at 4, 9.

55. Id.

56. Id.

57. See I.R.C. § 1(g)(1) (2006).

58. See id. Although most children subject to the kiddie tax will be taxable on unearned income at their parents' rate, certain high-earning children may owe more at their own top marginal rate than that of their parents. For example, in 2007, at age seventeen, Dakota Fanning earned an estimated \$4 million. \# 94 Dakota Fanning, ForBEs.COM (June 14, 2007, 6:00 PM), http://www.forbes.com/ lists/2007/53/07celebrities_Dakota-Fanning_7WGP.html. As a result, she is subject to the highest marginal tax rate. See I.R.C. § 1(c). Provided her parents were not in the top marginal tax bracket, Ms. Fanning could actually reduce her tax liability by applying her parents' rate to her unearned income.

59. See I.R.C. §§ 1(g)(4), 911(d)(2).

60. See id. § 1(g)(4)(A)(ii). For 2011, that amount is the greater of $\$ 1900$ or, if the child itemizes, the sum of $\$ 950$ plus the itemized deductions directly related to her net unearned income. See id.; Rev. Proc. 2010-40, 2010-46 I.R.B. 663, 665. 
gains-is included in net unearned income. ${ }^{61}$ Gifts, however, are excluded from the definition of gross income ${ }^{62}$ and would thus not be subject to the kiddie tax. ${ }^{63}$

After determining her net unearned income, the child must calculate her taxable income both applying and ignoring the kiddie tax. ${ }^{64}$ To calculate her tax liability in the absence of the kiddie tax, the child determines the amount of tax she would owe if she were an adult. ${ }^{65}$ Then, to calculate her tax liability under the kiddie tax, she must subtract her net unearned income from her taxable income. ${ }^{66}$ Under the kiddie tax, she is taxable at her own marginal rate on any wage, salary, professional fee, and other compensation income. ${ }^{67}$ But she is taxable at her parents' top marginal rate on all of her net unearned income. ${ }^{68}$ Her tax liability is the higher of her ordinary tax liability or her tax liability under the kiddie tax. ${ }^{69}$

The kiddie tax significantly increases the complexity of the Internal Revenue Code. ${ }^{70}$ Because of the requirements of the kiddie tax, if a child receives unearned income during a year, she must calculate both her ordinary tax liability and her kiddie tax liability ${ }^{71}$ the administrative expense and complexity are a direct result of her receipt of passive income-including interest on savings accounts and dividends and capital gains from investments. In addition, to comply with her filing requirements under the Code, the parent of any child subject to the kiddie tax must provide the parent's taxpayer identification number to her child, and her child must include the taxpayer identification number on her own tax return. ${ }^{72}$

Recognizing the complexity of complying with the kiddie tax, the Code allows a parent to elect to include her child's gross income on her

61. See I.R.C. $\S \S 1(\mathrm{~g})(4)(\mathrm{A})(\mathrm{i}), 911(\mathrm{~d})(2)$.

62. Id. § 102(a).

63. See id. §1(g)(4)(A)(i).

64. See id. §1(g)(1).

65. See id. §1(g)(1)(A).

66. Id. $\S 1(\mathrm{~g})(1)(\mathrm{B})(\mathrm{i})$.

67. See id.

68. See id. § $1(\mathrm{~g})(1)(\mathrm{B})(\mathrm{ii}),(\mathrm{g})(3)$.

69. See id. § $1(\mathrm{~g})(1)$.

70. See Deborah H. Schenk, Simplification for Individual Taxpayers: Problems and Proposals, 45 TAX L. REV. 121, 150-51 (1989).

71. See I.R.C. § $1(\mathrm{~g})(1)$.

72. Id. $\S 1(\mathrm{~g})(6)$. Besides the administrative obligations, requiring parents to provide their social security numbers to their children potentially raises privacy concerns. See, e.g., Edward J. Eberle, The Right to Information Self-Determination, 2001 UTAH L. REV. 965, 971 (“A person may rightly be concerned over the confidentiality of her SSN and its proper use.”). 
own tax return. ${ }^{73}$ The benefits of this election, however, are severely constrained. The election can only be made if the child's income for the year consists solely of interest and dividends. ${ }^{74}$ Otherwise, if a child has any passive income during any taxable year, she will be subject to the administrative costs and burdens of the kiddie tax. ${ }^{75}$

\section{THE FAMILY AS AN ECONOMIC UNIT}

Although the kiddie tax was enacted principally to prevent abusive behavior, commentators have attempted to justify on policy grounds its effective aggregation of a child's income with her parents' for tax purposes. The principal justification presented for taxing a child's passive income at her parents' rate is that the family is an economic unit and should be treated as such for tax purposes. ${ }^{76}$ Such aggregation, while uncommon, is not entirely novel to the tax law, and extensive literature debates whether the tax law should aggregate spousal income-effectively treating spouses as a single economic unit-or whether spouses should be taxed separately on their individual income. ${ }^{77}$

In debating whether the family should be taxed as an economic unit, commentators and policymakers are in essence trying to determine whether a family's taxpaying ability is better determined "'by total family income regardless of the distribution of such income among the members of the family"” or by " "the separate taxpaying abilit[y] of [each] individual member[] ... [as] determined by the amount of income of which he or she is the owner without reference to the income of other members of the family." "78 If family members pool their resources, it

73. See I.R.C. § $1(\mathrm{~g})(7)$.

74. See id. §1(g)(7)(A)(i).

75. See supra notes $57-72$ and accompanying text.

76. Thuronyi, supra note 7, at 599 ("As a matter of principle, there is a strong argument in favor of determining the rate of tax on income of family members by aggregating the family income and making an adjustment for family size ....”).

77. See, e.g., Anne L. Alstott, Tax Policy and Feminism: Competing Goals and Institutional Choices, 96 Colum. L. Rev. 2001, 2031-33 (1996); Boris I. Bittker, Federal Income Taxation and the Family, 27 Stan. L. Rev. 1389, 1431-42 (1975); Stephanie Hoffer, Adopting the Family Taxable Unit, 76 U. Cin. L. REV. 55, 101-03 (2007); Marjorie E. Kornhauser, Love, Money, and the IRS: Family, Income-Sharing, and the Joint Income Tax Return, 45 HASTINGS L.J. 63, 108-11 (1993); Edward J. McCaffery, Taxation and the Family: A Fresh Look at Behavioral Gender Biases in the Code, 40 UCLA L. REV. 983, 989-94 (1993); Henry E. Smith, Intermediate Filing in Household Taxation, 72 S. CAL. L. REV. 145, 155-56 (1998); Nancy C. Staudt, Taxing Housework, 84 GEO. L.J. 1571, 1594 (1996); Lawrence Zelenak, Marriage and the Income Tax, 67 S. CAL. L. REV. 339, 342 (1994).

78. Bittker, supra note 77, at 1392-93 (quoting TREASURY DEP'T, THE TAX TREATMENT OF FAMILY INCOME, reprinted in Hearings on Revenue Revisions Before the H. Comm. on Ways \& 
makes sense to treat a family as a taxpaying unit; if, however, they do not pool their resources, the economic argument for treating family members as a single taxpaying entity is far weaker. ${ }^{79}$

Ultimately, the reason aggregation may cause a family's net tax liability to differ from what the family members' tax liability would be if each paid taxes separately is because of the tax law's progressive marginal tax rates. With a truly flat rate structure, the family members would pay the same net tax, whether they were taxed as individuals or as an economic unit. $^{80}$ With a progressive tax, though, aggregating the income of a lower-earning family member-often called the "marginal earner" ${ }^{\prime 2}$ - essentially stacks her income on top of the higher-earning family member's income. As a result, "[t]he secondary earner's first dollar of income is effectively taxed at the primary earner's highest or 'marginal' rate." ${ }^{2}$ The marginal earner thus loses the benefit of paying taxes on some portion of her income at the lower marginal rates. ${ }^{83}$

Marriage throws a wrench into the design of a tax system. At first glance, marriage seems to create a quintessential economic unit, with both spouses jointly controlling marital assets. But on closer examination, nothing inherent to marriage requires couples to behave as an economic partnership. In fact, income shifting between married persons is possible and has occurred almost since the first modern U.S. tax law was passed. ${ }^{84}$ Ultimately, with the introduction of the joint return, Congress blessed income shifting between spouses. ${ }^{85}$

Means, 80th Cong. 846 (1947)).

79. Neoclassical economics treated the family as an individual, albeit one whose preferences were a "black box." Robert A. Pollak, Gary Becker's Contributions to Family and Household Economics, 1 REv. ECON. HousEHOLD 111, 122-23 (2003). Gary Becker introduced a model of family collective choice, an "altruist model," that posits, among other things, resource pooling in families. Id. at 122, 131. Subsequent empirical research, however, suggests that families do not simply pool their resources and allocate the pool to maximize a single, familial objective; rather, the person who earns the money maintains some level of control over the use to which that money is put. Id. at 131-33; see also infra notes 96-99 and accompanying text.

80. Susan Pace Hamill, An Argument for Tax Reform Based on Judeo-Christian Ethics, 54 AlA. L. REV. 1, 47 (2002) ("A flat or proportional income tax structure imposes the same percentage of tax on each taxpayer regardless of income level.”).

81. McCaffery, supra note 77, at 993.

82. Grace Blumberg, Sexism in the Code: A Comparative Study of Income Taxation of Working Wives and Mothers, 21 BufF. L. REV. 49, 52 (1971).

83. Staudt, supra note 77 , at 1609-10.

84. See, e.g., Lucas v. Earl, 281 U.S. 111, 114 (1930) (involving a husband and wife with a contractual arrangement to serve as "joint tenants" over all the couple's earnings).

85. See Staudt, supra note 77, at 1607 ("Pursuant to the joint return provisions adopted in 1948, spouses may aggregate their income and pay tax as a single unit according to the tax rate schedule for married couples filing jointly.”). 
But the joint return does not solve all of the problems that marriage introduces into the tax system. Ultimately, it is impossible to achieve progressivity, marriage neutrality, and couples neutrality. ${ }^{86}$ Under current law, married couples are generally treated as an economic unit. As an economic unit, a married couple files one tax return showing their aggregate taxable income and they jointly pay tax on that amount. ${ }^{87}$ Because one spouse's income is in effect stacked on top of the other's, that spouse loses the advantages of lower marginal rates applying to her income. $^{88}$ To ameliorate slightly the negative effects of stacking, there are separate tax rate schedules for married and unmarried persons, and the tax brackets for married people are wider than those for single people, though not twice as wide. ${ }^{89}$ Wider tax brackets permit a married couple to collectively earn more money than a single person before the couple's income pushes them into the next tax bracket. ${ }^{90}$ However, because the tax brackets for married couples are not twice as wide, a married couple can earn less collective income than two unmarried taxpayers would be able to earn before the couple is subject to the next higher marginal tax rate. ${ }^{91}$

Historically, commentators and policymakers took for granted that spouses acted as an economic unit. ${ }^{92}$ In spite of the long history of U.S. tax law permitting a married couple to aggregate income, recent scholarship disputes the conclusion that spouses should be treated as an economic unit. ${ }^{93}$ By stacking income, the joint return discourages the

86. "Progressivity means it matters how income is assigned among taxable units; marriage neutrality means marriage does not affect that assignment; and couples neutrality means marriage does affect the assignment. The incompatibility is apparent.” Zelenak, supra note 77, at 342.

87. Married couples are not required to file a joint return and, thus, to be treated as a single economic unit. Staudt, supra note 77 , at 1607 . The tax brackets for a married individual filing separately, however, are narrower than the brackets for unmarried individuals or for married individuals filing jointly. See I.R.C. § 1(a), (c)-(d) (2006); Rev. Proc. 2009-50, 2009-45 I.R.B. 617, 619-21. Everything else being equal, then, a married person is likely to file a joint return.

88. Staudt, supra note 77, at 1608-09.

89. Zelenak, supra note 77 , at 340 (“[A] joint-return system could be designed with marriage bonuses in some situations and marriage penalties in others. This could be accomplished by a jointreturn rate schedule whose brackets are wider than the brackets for single taxpayers, but less than twice as wide. The current law takes this approach.”).

90. See id. at 340 n.6.

91. See id. at 340 .

92. See, e.g., Blumberg, supra note 82, at 52 ("Aggregation of spousal income, as opposed to individual taxation of each spouse's income, is based on the indisputable economic unity of the family.”).

93. Despite Professor Blumberg's acknowledgment of the economic unity of the family, she nonetheless did not believe that spouses should aggregate their income for tax purposes. Id. at 95 ("The aggregation of spousal income should be abandoned in favor of individual taxation for all wage earners ....”). 
marginal earner-often the wife-from working by effectively taxing her first dollar of earnings at a relatively high marginal rate. ${ }^{94}$ Moreover, although marriage confers to one spouse certain property rights in the other spouse's property that are unavailable to nonspouses, ${ }^{95}$ it is not always the case that married couples share control over the family income in practice-strong empirical evidence shows that married couples do not pool all of their resources but, rather, the earner spouse often controls income. ${ }^{96}$ Because in many cases spouses do not act as an economic unit and because treating them as a unit can often have detrimental effects on the spouses individually and on their household finances, ${ }^{97}$ some tax scholars have suggested that the tax law should move away from treating even spouses as an economic unit. ${ }^{98}$

94. See Alstott, supra note 77, at 2009 ("Although the joint return applies a formally genderneutral tax rate schedule to a couple's aggregate income, wives are often viewed as 'secondary' workers, because they typically earn less than husbands and their jobs often are perceived as more dispensable.”).

95. See Cass R. Sunstein, The Right to Marry, 26 CARDOzo L. Rev. 2081, 2091 (2005) ("Under both state and federal law, spouses may have automatic ownership rights that non-spouses lack. In community property states, people have automatic rights to the holdings of their spouses, and they cannot contract around the legal rules. Even in states that do not follow community property rules, states may presume joint ownership of property acquired after marriage and before legal separation.”).

96. See Kornhauser, supra note 77, at 91 (“The evidence from empirical studies indicates that neither assertions of pooling nor nominal arrangement of assets in a pooling manner accurately reflect the reality of financial arrangements.”); see also Martin Browning et al., Income and Outcomes: A Structural Model of Intrahousehold Allocation, 102 J. POL. ECON. 1067, 1090 (1994) (" $[T]$ he influence of differential incomes and wealth on intrahousehold allocation can be fairly substantial.”); Shelly J. Lundberg et al., Do Husbands and Wives Pool Their Resources? Evidence from the United Kingdom Child Benefit, 32 J. Hum. ResourCEs 463, 479 (1997) ("Holding constant total family income, the income received by each spouse has substantial and significant effects on family expenditure patterns."). It is important to keep in mind that the fact "that spouses do not pool all their resources does not mean that they do not pool any resources.” Jens Bonke \& Hans UldallPoulsen, Why Do Families Actually Pool Their Income? Evidence from Denmark, 5 REV. Econ. HOUSEHOLD 113, 114 (2007).

97. See Kornhauser, supra note 77, at 64 ("By 'penalizing' the second worker, the joint return discourages married couples from having a second earner (usually the wife), putting both psychological and economic stress on these families, on the wife in particular.").

98. See, e.g., id. at 108 ("The joint return ought to be abolished. A system that treats each person as a separate taxable unit is more equitable, more consistent with basic tax principles, more efficient, and ultimately better able to accomplish social family goals.”); Smith, supra note 77, at 151 ('In this Article, I will explore a third alternative, which I call 'intermediate filing.' Instead of allowing couples to 'split' their income as joint filers or forcing them to file as individuals, intermediate filing presents couples with a choice of individual filing as a default or fractional splitting.”). But see Alstott, supra note 77, at 2080 (“[T]he traditional equal treatment rationale for individual filing is weaker than proponents have conveyed. ... Although individual filing might be structured to reinforce family law rules giving wives greater legal control over marital property, the most effective means of doing so would undermine the central goal of individual filing-eliminating the secondary-earner bias."); Hoffer, supra note 77, at 79 ("[T] he half-steps already taken by Congress demonstrate its acknowledgment of some level of economic interdependence among 
Although significant scholarship has demonstrated that families do not pool all of their resources, the research has generally focused solely on "the effects of the relative earning power of husbands and wives." 99 There has been little study of the effects of children's income on familial expenditures. ${ }^{100}$ Nonetheless, if the arguments against treating a married couple as an economic unit are compelling, the argument against treating children as being in an economic unit with their parents would seem to make at least as much sense, in part because the case for aggregating children's income with their parents' income is not founded in tax logic but in an "observer's perception of social realities."101 The objections marshaled against aggregating spouses' income-including that such aggregation discourages earning and that spouses do not, in fact, act as an economic unit ${ }^{102}$ - apply equally to aggregating children's income with that of their parents.

But additional objections also apply in the case of children. Adults opt into treatment as an economic unit, both by getting married and by choosing to file a joint return. If they wanted to be treated as distinct economic units, they could choose not to marry ${ }^{103}$ or not to file jointly. ${ }^{104}$ Children, on the other hand, cannot opt out of the kiddie tax. Until she turns twenty-four, earning passive income may drag a child into the kiddie tax, irrespective of her decisions. ${ }^{105}$

family members, and particularly children. ... By providing scattered benefits, Congress has failed to provide holistic treatment of the family. Adoption of the family as the taxable unit is a clear and simple remedy to that problem.").

99. Carolyn M. Moehling, "She Has Suddenly Become Powerful": Youth Employment and Household Decision Making in the Early Twentieth Century, 65 J. ECON. HIST. 414, 415 (2005).

100. See id.

101. Bittker, supra note 77 , at 1397.

102. See supra notes $92-98$ and accompanying text.

103. See, e.g., Sharon Jayson, Census Reveals More Couples: Direct Question Bumps Up Data, USA TODAY, July 29, 2008, at 6D ("The number of opposite-sex couples who live together has jumped from less than 1 million 30 years ago to 6.4 million in 2007 . . . Cohabitating couples now make up almost $10 \%$ of all opposite-sex U.S. couples, married and unmarried.”).

104. See I.R.C. § 1(d) (2006) (containing the rate schedule for married individuals filing separate returns).

105. See id. § 1(g)(2)(A) (Supp. II 2009). She could opt out, in theory, by getting married and filing a joint return. See id. $\S 1(\mathrm{~g})(2)(C)(2006)$. But even if this were a desirable result, in most states she could not do so until she was at least sixteen years old, meaning that somebody younger than sixteen would have no way to opt out. See, e.g., 750 Ill. COMP. StAT. ANN. 5/203(1) (West 1999). 
Although parents have an obligation to support their children, ${ }^{106}$ children do not have shared rights in their parents' property in the way that spouses have an interest in each other's property. ${ }^{107}$ Still, a child's income arguably reduces the amount that parents have to pay to support the child, effectively freeing the parents' money to be spent in other ways. $^{108}$

Even if a child's income reduces the amount her parents have to pay for her support in some cases, it does not follow that it frees her parents' money in every case. Children may spend their money on necessitiesfood and clothing, for example-for which their parents would otherwise have paid. But it is also possible for children to spend their money on nonessential items that their parents did not have any legal or moral obligation to provide and which their parents would not have otherwise purchased. That is, a child's income may facilitate additional, rather than substituted, consumption.

This intuition may be bolstered by research on the allocation of resources of families with working children in the early twentieth century. In contrast to today, where a child's income belongs to the child and where measures protect a child's resources even from her parents, ${ }^{109}$ in the early twentieth century, a child's earnings were seen as the property of her parents. ${ }^{110}$ But in spite of the fact that children's income

106. E.g., David Beck \& Sheldon V. Ekman, Where Does Support End and Taxable Gift Begin?, 23 N.Y.U. ANN. INST. ON FED. TAX'N 1181, 1183 (1965) (“It is generally recognized that a parent has the obligation to support minor children, regardless of the amount of property owned by the child.”); Marsha Garrison, Autonomy or Community? An Evaluation of Two Models of Parental Obligation, 86 CALIF. L. REV. 41, 50 (1998) ("Like his contemporaries, Blackstone held that the 'insuperable degree of affection' between parent and child was a sufficient guarantor of parental support to obviate the need for legal sanctions.... A hundred years after Blackstone, American family law recognized a paternal support obligation that was enforceable on behalf of the child, rather than the public, and which applied whether or not the child was in danger of becoming a public charge.”); John Stick, Turning Rawls into Nozick and Back Again, 81 Nw. U. L. REV. 363, 394 (1987) ("I grant that it is first the duty of the parents to support a child ....").

107. See, e.g., Stick, supra note 106, at 394 ("The child's right to support is not a property right. Parents have no duty to provide the child with property, only with shelter, food, drink, and clothing.").

108. See Bittker, supra note 77, at 1397 (“[A]s the children’s income grows, the parents are relieved of pressure to support the children currently and to pass on an inheritance to them.”).

109. See, e.g., Joseph M. Dodge, Beyond Estate and Gift Tax Reform: Including Gifts and Bequests in Income, 91 HARV. L. REV. 1177, 1205 (1978) ("Money and property saved by the minor child is not really available to the family as a whole."). In fact, to protect child performers' assets from being dissipated by their parents, California requires certain employers of minors to deposit fifteen percent of the minor's earnings into a "Coogan trust" account, where it cannot be used until the minor is emancipated or turns eighteen. See Saira Din, Chapter 667: Instituting Proper Trust Funds and Safeguarding the Earnings of Child Performers from Dissipation by Parents, Guardians and Trustees, 35 MCGEORGE L. REV. 473, 475 (2004).

110. Moehling, supra note 99, at 416 ("But, whereas today the earnings of working children are 
belonged to their parents, there is no evidence that working children lost control of their money as it was pooled with other household resources. Rather, there is "evidence that the income children brought into the household influenced household decisions. They may not have gained equal footing with their parents in all household decisions, but they had, through their work behavior, the ability to alter the allocation of resources within the household."111 Although no empirical evidence describes the pooling of children's income today, children likely have at least as much ability today, with their full ownership of their income, to alter their families' allocation of resources as children a century ago had.

In addition, a child may save some or all of her money and only spend it after she has moved away from her parents and they have stopped supporting her. ${ }^{112}$ As with the discretionary spending, this postchildhood spending often does not substitute for parental spending. As a matter of fact, even assuming that children are part of an economic unit that also includes their parents, children generally only remain part of an economic unit with their parents for a finite amount of timepresumably, a child will eventually leave home, get a job, and neither contribute materially to nor receive material support from her parents. ${ }^{113}$

Admittedly, a large number of marriages end in divorce, ${ }^{114}$ which also effectively terminates the prior economic unit between spouses, but the specter of possible divorce does not prevent married couples from being treated as a unit for tax purposes. ${ }^{115}$ The economic consequences of divorce, however, are significantly different from the economic consequences of a child's eventual emancipation. Upon divorce, the former spouses are typically required to make an equitable division of

viewed as the property of the children, in the past, those earnings were viewed as the property of the parents. Working children turned over most, or all, of their earnings to their parents.").

111. Id. at 436.

112. See Dodge, supra note 109, at 1205 ("To the extent that the savings are intended to provide for the time when the minor will form a separate tax unit, it would be unfair to tax these amounts at high marginal rates based on the combined income of the family.").

113. While many states have filial responsibility statutes that require adult children to provide care for or support to indigent parents, these statutes are rarely enforced. Jennifer M. Collins et al., Punishing Family Status, 88 B.U. L. REv. 1327, 1349 (2008) ("It bears mention that since the 1970s, the vast majority of state statutes requiring adult children to support their elderly and indigent parents have been enforced rarely or not at all, especially in the criminal context.”). In addition, some states, including Illinois, require one or both parents to pay for the educational expenses of nonminor children. See, e.g., 750 ILL. COMP. STAT. ANN. 5/513(a)(2) (West 2009).

114. See Elizabeth Warren, The New Economics of the American Family, 12 AM. BANKR. INST. L. REV. 1, 23 (2004) ("Pretty much everyone knows that newlyweds now face a high chance of splitting up (although the risk is slightly less than the 50/50 number that circulates as conventional wisdom).").

115. See I.R.C. § 1(a) (2006) (allowing married individuals to file joint tax returns). 
property, ${ }^{116}$ and one spouse potentially has a continuing financial obligation to the other. ${ }^{117}$ This division of property and future income reflects that an erstwhile economic unit has been divided, and so the economics of the unit have to be divided. ${ }^{118}$ In contrast, even parents who have a legal financial obligation toward their children are generally no longer financially obligated to their children when they reach the age of majority. ${ }^{119}$

The argument that the kiddie tax is intended to treat children as an economic unit with their parents is further, and more forcefully, belied by the fact that the tax law does not otherwise treat children as part of an economic unit. Children are taxed at their own marginal rate on all of their nonpassive income. ${ }^{120}$ That is true whether they get jobs on their own merits or because of their parents' connections, and it is true whether they work in a fast-food restaurant or as an intern in their mother's law firm.

There is no economic justification for treating a child as part of an economic unit with her parents with respect to her passive income but treating her as an individual taxable unit with respect to her nonpassive income. Money is fungible; its source does not affect its use. If it is true that a child's passive income reduces the amount her parents must pay to support her, it is equally true that her wage income reduces her parents' expenditures. This bifurcation demonstrates that the kiddie tax in its current form is not, in fact, supportable on the grounds that children and their parents form an economic unit. Instead, the kiddie tax functions solely as an anti-abuse rule.

116. 27B C.J.S. Divorce § 874 (2005).

117. See id. § 499 .

118. See Alicia Brokars Kelly, The Marital Partnership Pretense and Career Assets: The Ascendancy of Self over the Marital Community, 81 B.U. L. REV. 59, 69-70 (2001) ("The [marriageas-partnership] theory provides that spouses are partners who each make a set of meaningful, although perhaps different, contributions to the marital enterprise.... Therefore, each spouse is entitled to share in the marital estate because each participated in its acquisition. Under this view, the economic resource is apportioned, not based on need or status, but because it has been earned.”).

119. This is not to say that parents cannot, or do not, continue to support their children after the age of eighteen. However, parents are not generally required to do so. Elizabeth S. Scott, The Legal Construction of Adolescence, 29 HOFSTRA L. REV. 547, 559 (2000) ("The financial support obligation of parents generally ends when children attain the age of majority, as does parents' common law right to their children's earnings.”). In some states, however, an adult child can sue for retroactive child support. See, e.g., Tedford v. Gregory, 1998-NMCA-067, ๆ 48, 125 N.M. 206, 959 P.2d 540; Carnes v. Kemp, 104 Ohio St. 3d 629, 2004-Ohio-7107, 821 N.E.2d 180, at 918.

120. The Code is explicit on this point: even if compensation for a child's services is paid to one of her parents, or to anybody else other than the child, the compensation is nonetheless includible in the child's gross income. I.R.C. § 73(a) (2006). 


\section{EVAluating the EFFECTIVENESS OF THE KIDDIE TAX}

\section{A. The Kiddie Tax Is Overbroad and Distorts Children's Nonabusive Economic Decisions}

For the U.S. economy to be healthy, some amount of current consumption is necessary. But a healthy economy must balance current consumption against saving and investing for future consumption. ${ }^{121}$ Saving and investing are socially beneficial because they may produce positive externalities, benefiting not only the savers but society in general. ${ }^{122}$ It is not clear exactly what savings rate is optimal for the United States, but people generally agree that Americans save too little. ${ }^{123}$ As recently as 2006, the U.S. savings rate actually became negative. ${ }^{124}$ Even in the midst of the recession of 2009, the U.S. savings rate, at five percent, remained half of the savings rate as recently as the 1980s. ${ }^{125}$

121. A common argument in favor of savings is that "in the long run, [saving] leads to greater productivity and technology gains.” Edward J. McCaffery, Tax Policy Under a Hybrid IncomeConsumption Tax, 70 TEX. L. REV. 1145, 1161 (1992). Implicit, but often unsaid, is a cultural argument: that saving leads to thrift and, as such, is "emblematic of virtue." Id. at 1162.

122. Daniel N. Shaviro, Reckless Disregard: The Bush Administration's Policy of Cutting Taxes in the Face of an Enormous Fiscal Gap, 45 B.C. L. REV. 1285, 1309 (2004) ("Increased national saving, however, is thought by many to benefit people other than the savers themselves-in particular, younger people and future generations, who may benefit if productive use of the savings enables them to live in a more affluent society.”).

123. See Stefan Theil, The Urge to Splurge, NEwsweEK, Dec. 6, 2010, at 26, 28 ("If, as we've all been told, the nation's long-term economic health depends on boosting savings and paring debt ... then we haven't made very much headway.”); see also B. Douglas Bernheim \& John Karl Scholz, Private Saving and Public Policy, 7 TAX POL'y \& ECON. 73, 73 (1993) ("The evidence presented in this paper supports the view that many Americans, particularly those without a college education, save too little.”); Melissa A.Z. Knoll, The Role of Behavioral Economics and Behavioral Decision Making in Americans' Retirement Savings Decisions, Soc. SECURITY Bull., Nov. 2010, at 1, 2-3 ("Americans appear to want to make sound financial decisions: They want to spend less and save more. However, Americans' actual savings represent less than 5 percent of their disposable income.”).

124. See Edmund L. Andrews, With Housing in a Slump, Mortgages Rose Anyway, N.Y. TIMES, Mar. 9, 2007, at C2 ("Analysts said that homeowners continued to stretch their resources last year, when household savings rates dipped into negative territory, below zero, and that many people might be at the limit of how much they could borrow.”). The savings rate can be negative when people borrow to fund consumption in excess of their net worth. See Catherine Rampell, Optimism as Spending Rises Again, N.Y. TIMES, Mar. 28, 2009, at B3 ("Those figures show Americans to be much thriftier than they were in recent years, when personal savings rates hovered around zero and even dipped into negative territory as consumers took on more debt.”).

125. Edmund L. Andrews, Obama Aides See Signs of Recovery but Say It Will Be Slow, N.Y. TIMES, Aug. 3, 2009, at B1. Throughout 2009, the personal savings rate fluctuated "from a low of 3.4 percent in February to a high of 6.4 percent in May," the highest rate since 1993. Ron Lieber, We're Saving Again. What Happened?, N.Y. TIMES, Dec. 19, 2009, at B1. 
By taxing children's passive income at their parents' top marginal rate, the tax system distorts children's incentives for both investing and saving. ${ }^{126}$ Because children can often avoid the higher rates imposed by the kiddie tax by continuing to hold the investment until they reach an age at which it no longer applies, the kiddie tax may not discourage children from investing, but it increases the lock-in effect and affects the type of investments children are willing to make. Because the tax system only taxes realized gain, the lock-in effect discourages a taxpayer who holds appreciated property from selling that property. ${ }^{127}$ If the taxpayer instead continues to hold the property, her wealth continues to increase but she is not liable for taxes. The lock-in effect is perhaps the principal justification for taxing capital gains at a lower rate than that at which wage income is taxed. ${ }^{128}$ Currently, taxpayers in the lowest two brackets pay no taxes on their long-term capital gains. ${ }^{129}$ Under the kiddie tax, however, a child otherwise subject to no tax on her long-term capital gains would generally pay tax at her parents' rate of fifteen percent. ${ }^{130}$ Under current law, the lowest marginal tax bracket taxes income at ten percent. $^{131}$ If a child were subject to the lowest marginal rate on her earned income, but were subject to the kiddie tax on her passive income, she would pay taxes at a rate five percentage points higher on her longterm capital gains than she would on her wage income. This significantly exacerbates the lock-in effect because she can avoid this higher rate of tax by holding onto her investments ${ }^{132}$ until after she turns eighteen or, if she is a full-time student, twenty-four. ${ }^{133}$ In the year that she is no longer subject to the kiddie tax, a child is likely to still be in a

126. See Lawrence H. Summers, Tax Policy, the Rate of Return, and Savings 1 (Nat'l Bureau of Econ. Research, Working Paper No. 995, 1982) ("Both the theoretical analysis and the empirical work demonstrate the strong likelihood that increases in the real after-tax rate of return received by savers would lead to substantial increases in long run capital accumulation.”). It is worth noting that the children themselves may not consciously evaluate whether, in light of their taxes, they should invest or spend. But whether the children, their parents, or their investment advisors make the investment decision, ultimately, the money belongs to the children and they can control how they save or spend it.

127. See Noël B. Cunningham \& Deborah H. Schenk, The Case for a Capital Gains Preference, 48 TAX L. REV. 319, 344 (1993) (“The lock-in effect describes an investor's reluctance to incur a tax on realization of gains ....”).

128. See id. ("The most serious argument in favor of a capital gains preference is premised upon the so-called lock-in effect.").

129. See I.R.C. § 1(h)(1)(B) (2006).

130. See id. §1(h)(1)(C).

131. See id. § 1(i)(1)(a)(ii).

132. See Cunningham \& Schenk, supra note 127, at 344.

133. See supra notes $46-50$ and accompanying text. 
lower tax bracket and thus will likely be able to realize her gains at a zero rate.

In addition, the kiddie tax discourages children from investing in dividend-paying securities. Like capital gains, under current law, dividends from most U.S. corporations-called "qualified dividend income"-are taxed at a fifteen-percent rate but are taxed at a zeropercent rate to people in the lowest two tax brackets. ${ }^{134}$ However, under the kiddie tax, children in the lowest tax bracket would generally be taxable on their qualified dividend income at a fifteen-percent rate; again, this is five percentage points more than they pay on their ordinary income. $^{135}$ Moreover, if dividend income is not qualified dividend income-because, for example, it is paid by certain foreign corporations - it would be taxable at ordinary rates - up to twenty-five percentage points more than the child would pay on wage income! $!^{136}$

Because she can defer the realization of her investments and ultimately pay no taxes when she does sell the investments, the U.S. government is unlikely to receive significant amounts of additional revenue from the higher tax rate imposed by the kiddie tax. This process, however, subjects children to significant detriments. First, they are encouraged to invest in non-dividend-paying growth stocks, even if, absent tax considerations, they would prefer to invest in dividend-paying stocks. In addition, children are discouraged from selling their stocks before their eighteenth birthday, even in the event of a change in circumstances or investment strategies or if they have a shorter investment horizon. Finally, the kiddie tax makes it difficult for children to adequately diversify their portfolios. For most investors, mutual funds are the most effective way to invest their money and achieve diversification. $^{137}$ But mutual funds buy and sell securities, realizing

134. See I.R.C. § 1(h)(1), (11).

135. See supra note 131 and accompanying text.

136. These numbers assume that the child is in the lowest tax bracket and her wage income is taxable at a rate of ten percent, while her parents are in a higher tax bracket, with a marginal tax rate of up to thirty-five percent. See I.R.C. § 1(i) (2006 \& Supp. II 2009).

137. See John C. Coates, IV, Reforming the Taxation and Regulation of Mutual Funds: A Comparative Legal and Economic Analysis, 1 J. Legal ANALYsis 591, 591 (2009) ("Over the past 50 years, mutual funds have become the primary way middle class Americans invest ....”); Allan F. Conwill, Blight or Blessing? The Wharton School Study of Mutual Funds, 18 Bus. LAW. 663, 667 (1963) ("[A]n investor of moderate means cannot achieve the diversification provided by most funds by individual investment in selected stocks. Unless he has substantial funds available, he cannot buy each of the one hundred or more securities which are in the portfolio of the typical mutual fund. Thus, the mutual fund provides the modest investor with an easy and convenient vehicle for achieving diversification.”); Robert C. Illig, The Promise of Hedge Fund Governance: How Incentive Compensation Can Enhance Institutional Investor Monitoring, 60 ALA. L. REV. 41, 83-84 
both long-term and short-term capital gains_-and sometimes dividend income-annually and are required to pass the bulk of their gains and income through to their shareholders annually. Shareholders are then liable to pay taxes annually on such gains and income. ${ }^{138}$

Even if children are not interested in investing, the kiddie tax emphasizes current consumption by discouraging saving. Interest is taxable at ordinary tax rates. ${ }^{139}$ Under the kiddie tax, however, interestincluding interest on savings accounts-is taxable at a child's parents' marginal rate. Moreover, the child's interest income is effectively stacked on top of her parents' income. ${ }^{140}$ That is, she is taxed from her first taxable dollar at her parents' rate. Although economists disagree on how and to what extent an individual's savings decisions are influenced by the tax rate, ${ }^{141}$ economic theory suggests that the decision of whether to save for the future or to spend money currently is influenced, at least in part, by the after-tax rate of return of an investment. ${ }^{142}$ Assuming that

(2008) (“[Mutual funds'] primary function is to provide the benefits of diversification to investors with relatively small portfolios.”); Alan R. Palmiter \& Ahmed E. Taha, Star Creation: The Incubation of Mutual Funds, 62 VAND. L. REV. 1485, 1490 (2009) (“Ownership of mutual funds is widespread. Of the 116 million households in the United States, almost 52.5 million (or 45 percent) own mutual funds, far more than hold individual securities, such as stocks and bonds.").

138. See I.R.C. § 852 (2006 \& Supp. II 2009).

139. See id. § 1(a)-(e) (2006) (imposing the income tax on "taxable income”); id. § 63(a) (defining "taxable income" to include "gross income"); id. § 61(a)(4) (defining "gross income" to include interest).

140. See supra note 58 and accompanying text.

141. See Martin J. McMahon, Jr., The Matthew Effect and Federal Taxation, 45 B.C. L. REV. 993, 1084-88 (2004) ("The reality is that the motivations for saving and the decision of whether to save or consume are so complex that economic theory cannot deal with them very well."). Essentially, if the substitution effect predominates, an increased after-tax rate of return will cause people to increase their amount of saving relative to consumption, whereas if the income effect predominates, an increased after-tax return may cause people to save less because "a target saver can reduce savings and still have the same accumulated fund in a future year.” Id. at 1084.

142. Economic theory suggests, and intuitively it makes sense, that a person's propensity for saving is influenced by the after-tax return she can earn. A higher return will increase her savings relative to her consumption. Empirical studies support the theory, and other studies appear to contradict it. See, e.g., Bernheim \& Scholz, supra note 123, at 94 ("Economic theory suggests that households will respond to a higher after-tax rate of return by increasing future consumption relative to current consumption. However, the increase in anticipated future net worth resulting from higher rates of return may actually induce households to save less.”); McMahon, supra note 141, at 1084 ("Some economists conclude that personal savings responds significantly to the interest rate. Many other economists conclude that there is little if any response; it is 'small and hard to find."' (quoting Charles L. Schultze, Promises, Promises: The Elusive Search for Faster Economic Growth, BROOKINGS REV., Fall 1996, at 6, 8)). The difference between practice and theory may be explained, at least in part, by the complexity of all of the factors that a person considers in making the decision whether to save or consume, including phase-outs of certain benefits and qualification for others. See Laurence J. Kotlikoff \& David Rapson, Does It Pay, at the Margin, to Work and Save? Measuring Effective Marginal Taxes on Americans' Labor Supply and Saving, 21 TAX POL'Y \& ECON. 83, 84 (2007) ("Yet any American seeking to understand her total effective net marginal 
the child is subject to tax at a ten-percent rate and that her parents are in the highest tax bracket, then rather than keeping nine dollars for every ten dollars of interest she earns, she will only keep \$6.50. The twentyfive additional percentage points that she has to pay in tax may, at least on the margin, convince her that she is better off spending her money today, even if there is something more expensive that she would rather spend her money on in the future, because of the diminished return on her investment.

It is important to keep in mind that the purpose of the kiddie tax is not to affect the investment, savings, or consumption choices of children. It is intended to prevent adults-in particular parents and grandparentsfrom reducing their aggregate tax burden by giving income-producing assets to their children and grandchildren. ${ }^{143}$ A child's decision to save or invest her money is not an abusive decision, and the kiddie tax overreaches its anti-abuse purpose if it distorts that decision.

As a partial corrective to the kiddie tax's overreach, the tax law contains a number of provisions that diminish its sting. The kiddie tax does not kick in, for example, until after a child has earned a threshold amount of passive income. ${ }^{144}$ In addition, the Code provides for a number of tax-advantaged savings accounts. ${ }^{145}$ But none of these partial solutions fully offsets the kiddie tax's ability to distort saving and investment.

It is true that the brunt of the kiddie tax falls on children of wealthy taxpayers. Still, "[w]hile it is possible to argue that any complexity attributable to the kiddie tax should not be of major concern because it applies primarily to wealthy taxpayers who can afford sophisticated tax advice, it seems clear that the rules also impinge on taxpayers who cannot readily afford such advice.”146 Although the kiddie tax provides

tax on either choice [working or saving] faces a daunting challenge. First, she needs to consider a host of taxes and transfers.... Second, she needs to understand in very fine detail how each of these taxes and transfers is calculated. Third, she needs to understand the interactions of the different tax and transfer programs. Fourth, she needs to consider the fact that these taxes and transfers are paid and received over time. And fifth, she needs to have a method for translating all of these interconnected time-dated tax payments and benefit receipts into a simple and comprehensible statement of her marginal reward for working and saving."). In the case of the kiddie tax, on the other hand, the calculus is fairly simple: Given the after-tax rate of return and the administrative burdens associated with calculating and reporting the kiddie tax, is it preferable for the minor to save her money for consumption in the future or to spend the money now?

143. See supra notes $6-10$ and accompanying text.

144. See I.R.C. $\S 1(g)(4)(A)(i i)$ (2006). The threshold amount for paying the kiddie tax is indexed to inflation. For 2011, that threshold amount is not less than $\$ 1900$. See id.; Rev. Proc. 2010-40, 2010-46 I.R.B. 663, 665.

145. See, e.g., I.R.C. § 529.

146. Schenk, supra note 70 , at 150. 
that a threshold amount of unearned income is exempt from its higher rates, the kiddie tax remains overbroad. Assuming the minor can earn an annual return of five percent on her savings and investment, all she needs is $\$ 38,000$ of investable assets to meet the threshold for 2011 . $^{147}$ If she manages a ten-percent return, the amount she needs to invest drops to $\$ 19,000 .{ }^{148}$ While these are significant amounts, it is not impossible for a minor to have that much money, especially if she has earned money and has received gifts over the course of her life. ${ }^{149}$

It is important to note that the purpose behind the kiddie tax is not to cause children to be taxed on gifts they have received; Congress has determined that gifts do not constitute gross income and has not limited that determination to gifts for adults. ${ }^{150}$ Rather, the kiddie tax was intended solely as an anti-abuse rule to prevent income shifting and cannot be justified on other grounds. ${ }^{151}$

Under current law, minors have avenues to save and invest their money and not pay taxes on the passive income at their parents'-or any other-marginal rate. Most notably, provided she meets the prerequisite requirements, a child can put her money in a tax-advantaged education savings plan, such as a 529 plan, or in an individual retirement account.

\footnotetext{
147. $\$ 38,000 \times 0.05=\$ 1900$.

148. $\$ 19,000 \times 0.10=\$ 1900$.
}

149. For example, in 2010, the minimum wage in San Francisco was $\$ 9.79$ an hour. Office of Labor Standards Enforcement, Gen. Servs. Agency, Minimum Wage Ordinance (MWO), CITY \& COUNTY OF SAN FRANCISCO, http://sfgsa.org/index.aspx?page=411 (last visited Nov. 19, 2010). If a sixteen-year-old were to work twenty hours per week at a minimum-wage job, after one year she would have earned $\$ 10,181.60$ from her job. If she were to invest that money and earn a ten-percent return, a portion of her investment income would be taxable at her parents' rate. After two years, she would have earned $\$ 20,363.20$, enough that a five-percent return would subject a portion of her passive income to the kiddie tax. And because the cut-off for the kiddie tax to apply has been raised from fourteen to twenty-four years old, her passive returns could potentially be taxable for another six years.

150. See I.R.C. § 102(a).

151. See Blattmachr, supra note 33, at 48 ("Now, however, the Tax Reform Act of 1986 presents additional statutory hurdles [including the kiddie tax] in an attempt to hinder the shifting of income.”). Professor Thuronyi argued that the kiddie tax could be justified more broadly by an appeal to the Haig-Simons concept of income. Thuronyi, supra note 7, at 591. But because doing so would require measuring each family member's income and consumption over the course of each year, practical considerations justified aggregating all family members' income. Id. This argument would have some purchase if the kiddie tax aggregated all of a child's income with her parents; however, because the kiddie tax only taxes a child's passive income at her parents' marginal rate, the kiddie tax cannot be justified by appealing to the child as part of an economic unit with her parents. See supra Part IV. As the age limit for the kiddie tax has been raised, the kiddie tax has begun to look less like an anti-abuse provision and more like a revenue raiser. 
A 529 plan is a state-run education savings program. ${ }^{152}$ By investing her money through a 529 plan, a child can earn a tax-free return on that money. ${ }^{153}$ Moreover, unlike most tax-deferred investments, withdrawals from a 529 plan are also tax free, provided they are used to pay for qualified educational expenses. ${ }^{154}$ There is also no limit on the amount that may be contributed to a 529 plan, provided the 529 plan has adequate safeguards to prevent contributions in excess of what will be necessary to meet the child's qualified educational expenses. ${ }^{155}$

If a child has earned income, she can also save and invest her money through an individual retirement account. An individual retirement account allows taxpayers to invest their money without paying taxes on any income earned on the investment until the money is withdrawn. ${ }^{156}$ In general, distributions are taxed at the taxpayer's own marginal rate. ${ }^{157}$ However, if money is withdrawn before a taxpayer is fifty-nine-and-ahalf years old, the tax law imposes a ten-percent penalty in addition to the ordinary tax that is due. ${ }^{158}$ Certain exceptions apply to this penalty, including if the money is withdrawn by a qualified first-time homebuyer ${ }^{159}$ or is used to pay certain higher-education expenses. ${ }^{160}$

Although these and certain other tax-advantaged savings vehicles can be used to allow a child to save money without paying taxes on income earned on that money at her parents' marginal tax rate, the uses to which she can put the money are drastically limited. Essentially, she can save for college, a home, or retirement. While these are all worthy and important goals, a child may have other short- or medium-term investment goals. Children are discouraged from saving for such

\footnotetext{
152. See Mercer E. Bullard, The Visible Hand in Government-Sponsored Financial Services: Why States Should Not Be Allowed to Offer 529 Plans, 74 U. CIN. L. REV. 1265, 1267 (2006). In fact, there are two types of 529 plans: one allows for prepaid tuition at in-state colleges and universities, see I.R.C. § 529(b)(1)(A)(i), while the other allows for the investment of money on a tax-free basis to meet college expenses. See id. § 529(b)(1)(A)(ii). This Article will only discuss the second type of 529 plan.

153. See id. § 529(a).

154. Bullard, supra note 152, at 1268.

155. See I.R.C. § 529(b)(6).

156. George Salimbas, Educational Opportunities for Taxpayers, 18 AKRON TAX J. 1, 9 (2003).

157. Id. at 9-10.

158. See I.R.C. § 72(t)(1), (2)(A)(i).

159. See id. § 72(t)(2)(F), (8).

160. See id. § 72(t)(2)(E), (7).
} 
goals, ${ }^{161}$ however, because they will pay taxes on interest earned on their money at their parents' higher rate of tax. ${ }^{162}$

As a result of the overbreadth of the kiddie tax, children can be required to pay taxes at their parents' higher tax rate, even on income that does not result from tax-motivated income shifting. Moreover, the overbreadth of the kiddie tax introduces significant distortions into children's financial planning, encouraging immediate consumption over medium- and long-term savings and investment. The kiddie tax was not designed to affect children's economic decisions and cannot be justified on such grounds.

\section{B. In Spite of Its Overbreadth, the Kiddie Tax Fails to Prevent Adults from Shifting Unrealized Income to Their Children}

Even more glaring than its inability in many cases to discourage the shifting of future income is that in most cases, the kiddie tax does not prevent high-income taxpayers from shifting unrealized appreciation to children. Under current law, giving a gift is not treated as a realization event. ${ }^{163}$ Moreover, gifts are excluded from the donee's taxable income. ${ }^{164}$ As a result, the donor never pays tax on the asset's appreciation, and the built-in gain is carried over to the donee, who will not pay any taxes on the gain until she sells the asset. ${ }^{165}$

Parents do not have an unlimited ability to shift unrealized appreciation to their children. The kiddie tax prevents shifting appreciated assets if the donor wants to immediately sell the asset and realize the appreciation. ${ }^{166}$ Capital gains are unearned income for purposes of the kiddie tax, so if the child were to sell the appreciated property while still subject to the kiddie tax, any gain would be taxable at her parents' rate in the same way interest and dividends are taxable at her

161. A child's medium-term consumption goals may include purchasing a car, computer, musical instrument, or other good that is expensive enough that she will need to save to purchase it but that she should be able to purchase before she is no longer subject to the kiddie tax.

162. See supra notes 139-42 and accompanying text.

163. See Marjorie E. Kornhauser, The Constitutional Meaning of Income and the Income Taxation of Gifts, 25 ConN. L. REV. 1, 43 (1992) (“[A] gift remains largely a nontaxable event for donors for income tax purposes ....”).

164. See id. § 102(a).

165. The donee will be taxed on unrealized appreciation when she sells the property because she takes the property with a carryover basis equal to the donor's adjusted basis in the property immediately before the gift. See I.R.C. § 1015(a).

166. See supra note 127 and accompanying text. 
parents' rate. ${ }^{167}$ But the ability of the kiddie tax to prevent shifting appreciated assets is limited by the fact that, if the child waited to sell it until after she ages out of the kiddie tax, any gain would be taxed at her-presumably lower-marginal rate. In the meantime, if the donor or the donee wants to monetize the appreciation, she can borrow against the asset without incurring any tax liability. ${ }^{168}$

Additionally, parents' ability to transfer assets to their children tax free is limited by the gift tax. ${ }^{169}$ The gift tax was originally enacted to backstop the income and estate taxes and to prevent income shifting. ${ }^{170}$ The gift tax limits the value of gifts a person can make in any given year, ${ }^{171}$ as well as over the course of the person's life. ${ }^{172}$

Still, the barrier presented by the gift tax against transferring appreciated assets is insignificant at best. Because of the high lifetime exemption - an individual can make gifts worth, in the aggregate, up to $\$ 1$ million over her lifetime without being subject to the gift $\operatorname{tax}^{173}$-and a relatively high annual exemption- $\$ 13,000$ in $2011^{174}$ - the gift tax does not apply to most gifts and, as a consequence, raises very little revenue. ${ }^{175}$ Moreover, the gift tax is difficult to enforce, and "substantial amounts of wealth are transferred without the payment of any transfer tax." ${ }^{176}$ Ultimately, the kiddie tax is virtually powerless to prevent wealthy taxpayers from shifting unrealized appreciation to their children, even with the backstop of the gift tax.

\footnotetext{
167. See supra Part V.A.

168. Borrowers are not taxed on the proceeds of a loan under the theory that they have no accession to wealth - the borrowed cash is immediately offset by the liability to repay the amount borrowed. Joseph M. Dodge, Exploring the Income Tax Treatment of Borrowing and Liabilities, or Why the Accrual Method Should Be Eliminated, 26 VA. TAx REV. 245, 247 (2006). "This treatment of borrowing has become so ingrained in the income tax that it was thought not to be necessary to enact a statutory borrowing exclusion.” Id. at 254.

169. I.R.C. §§ 2501-2524 (2006 \& Supp. II 2009).

170. Mitchell M. Gans \& Jay A. Soled, Reforming the Gift Tax and Making It Enforceable, 87

B.U. L. REV. 759, 761-62 (2007).

171. See I.R.C. § 2503(b) (2006).

172. See id. § 2505(a).

173. See id.

174. Rev. Proc. 2010-40, 2010-46 I.R.B. 663, 666. The annual exclusion from the gift tax is adjusted for inflation each year using the consumer price index. See I.R.C. § 2503(b)(2).

175. In 2005, the gift tax accounted for less than $0.1 \%$ of the overall revenue raised by the federal government. Gans \& Soled, supra note 170, at 760 .
}

176. Id. 


\section{TINKERING WITH A FLAWED REGIME}

Even as originally enacted, the kiddie tax was not perfectly targeted toward ending income shifting between parents and children. In part, this is because Congress had to navigate a line between preventing intrafamilial income shifting and administrability. For example, in an ideal world, the kiddie tax would only apply to income from property that, in spite of being formally owned by a child, was actually controlled by her parents. However, because "a case-by-case approach would be unworkable and would draw too heavily upon the [Internal Revenue] Service's scarce resources," ${ }^{177}$ the kiddie tax assumes all property is controlled by the parents. In the interest of administering the kiddie tax, Congress planted the seeds of the kiddie tax's overbreadth.

In other cases, it is not clear why Congress made the choices it made. Its principal concern was gifts from parents to children. ${ }^{178}$ Other adults could also reduce the government's net tax revenues by giving incomeproducing property to unrelated children, but they would be less likely to continue to exercise control over the property. In addition, it is possible for children to earn passive returns on income they have earned themselves. ${ }^{179}$ As such, it is unclear why Congress felt it necessary to apply the kiddie tax to all of a child's passive income in excess of the exemption amount. ${ }^{180}$ It is clear, however, that the broader kiddie tax that was originally implemented captures income it was not passed to capture, and as such, it can distort children's saving and consumption decisions. ${ }^{181}$

Almost immediately after its passage, Professor Leo Schmolka proposed significant changes to the design of the kiddie tax. Specifically, he sought to simplify the kiddie tax by applying the compressed tax brackets applicable to trusts and estates to every person for whom a dependency deduction could be taken. ${ }^{182}$ By applying such a

\footnotetext{
177. Thuronyi, supra note 7 , at 590 .

178. See id. at 590-91.

179. See supra notes $146-49$ and accompanying text.

180. Professor Thuronyi does not explain the underlying rationale for going beyond the Treasury Department's original proposal, but he argues that this broader reach is justified because "[t]he bulk of unearned income of minor children comes from the parents." Thuronyi, supra note 7, at 590-91. Even if this is true, though, it means that the original proposal of applying the kiddie tax solely to property received from parents would still tax virtually all of a child's unearned income without taxing passive income that was not a result of transfers from the parents.

181. See supra Part V.A.

182. See Schmolka, supra note 11 , at 117.
} 
rate structure in 2011, a child's income in excess of $\$ 11,200$ would be taxable at the highest marginal rate. ${ }^{183}$

Such a change would discourage tax-motivated income shifting because a child's income would almost immediately be taxable at the highest rate. In addition, it would eliminate complexity. Children would not have to bifurcate their active and passive income, would not have to do two calculations, and would not have to determine their parents' marginal tax rate. But, even more than the current implementation of the kiddie tax, Professor Schmolka's proposal is overbroad because it would continue to encourage consumption over saving and investment by significantly reducing the child's after-tax return. In addition, because both passive and active income would be taxed at higher rates, it would also significantly discourage a child from working. ${ }^{184}$ Where the current kiddie tax only discourages children from saving and investing, ${ }^{185}$ the proposed changes would discourage children from entering the world of money at all.

While Congress did not implement Professor Schmolka's proposals, the kiddie tax has not been entirely static. Over the last twenty-five years, Congress has tinkered with the kiddie tax, making small changes, including adding the election to put a child's unearned income on her parents' tax return ${ }^{186}$ and changing the age at which the kiddie tax no longer applies. ${ }^{187}$ Although these changes appear relatively easy to make, they generally fail to address the problems inherent in the kiddie tax; none of these changes has diminished the distortions created by the kiddie tax, and none has addressed the problem of shifting unrealized appreciation. For the kiddie tax to effectively prevent income shifting while diminishing the distortions it causes, it will require changes that are more fundamental than what Congress has done so far.

183. See Rev. Proc. 2009-50, 2009-45 I.R.B. 617, 621 tbl.5. That is in comparison with the $\$ 373,650$ a child would have to earn to be in the highest tax bracket under current law. See id. at 620 tbl.3. The rate structure applicable to 2010 has not been changed for 2011. See Rev. Proc. 2010-40, 2010-46 I.R.B. 663, 664.

184. A child would be discouraged from working because of the "substitution effect." See McCaffery, supra note 77, at 1037 ("Substitution effects unambiguously lead the individual away from the taxed activity, as other goods or pursuits ('substitutes') become more attractive.”). Because her family is unlikely to rely on her income to survive, her need to work is relatively elastic, and she can substitute leisure for work. See id. at 1038-39 ("But a good deal of evidence supports the proposition that the labor elasticity for secondary earners in general, and married women in particular, is higher than it is for primary earners, or husbands.”).

185. See supra Part V.A.

186. See I.R.C. § 1(g)(7) (2006).

187. See supra notes $46-50$ and accompanying text. 


\section{VII.DESIGNING A GROWN-UP KIDDIE TAX}

For the kiddie tax to grow up and effectively prevent the income shifting it was passed to prevent, the kiddie tax needs to be rethought and redesigned almost from the ground up. The grown-up kiddie tax still bifurcates a child's income, but instead of bifurcating it between earned and unearned income, it comes closer to the original vision of the kiddie tax.

To further explain the grown-up kiddie tax, it is important to note that it is not entirely different than the current version. Just as an adult generally bears some resemblance to her younger self, the grown-up kiddie tax keeps the rough structure of the current kiddie tax. Any income that is subject to the kiddie tax will generally be taxed at the parents' marginal rate. ${ }^{188}$ Other income will continue to be taxed at the child's marginal rate. The main change is in what income is encompassed by the kiddie tax.

\section{A. A Broad Outline of the Grown-Up Kiddie Tax}

As originally proposed, the kiddie tax would have only applied to income on assets transferred from a parent to her child. ${ }^{189}$ Although structuring the kiddie tax in this manner would have avoided the overbreadth of the current kiddie tax, parents could have easily avoided the kiddie tax. A parent would have been able to essentially launder the asset, giving it to a third party with the stipulation that the recipient pass it on to the parent's child. ${ }^{190}$ Alternatively, a high-income taxpayer could find another high-income taxpayer who owned an economically similar asset, and the first could give her asset to the second's child, while the second gave her asset to the first's child. In any event, while it may raise the transaction costs associated with income shifting, limiting the kiddie tax to income from parent-to-child asset transfers would have been too narrow to effectively prevent income shifting.

Instead of bifurcating between earned and unearned income or between income-producing assets received from a child's parents and all

188. As with the current kiddie tax, a child will not always pay at her parents' marginal rate. If the child is in a higher tax bracket than her parents, the grown-up kiddie tax will continue to require her to pay taxes at her own marginal rate. See supra note 58.

189. See Thuronyi, supra note 7 , at 590.

190. It is even possible to imagine an industry built around this transaction, with accommodation parties charging a fee-determined as an amount less than the tax savings to the parent- to hold the asset and then give it to the child. 
other income, the grown-up kiddie tax would divide a child's income between income earned on assets received as a gift-without regard to the identity or age of the donor-and all other income. By dividing a child's income in this way, the grown-up kiddie tax reduces the overbreadth of the current kiddie tax while continuing to discourage income shifting. In addition, the grown-up kiddie tax would apply to assets received before the child had aged out, rather than just to income realized while the child was still subject to the kiddie tax.

As such, the kiddie tax would continue indefinitely to capture income from income-producing assets given to children. But it would also capture unrealized appreciation transferred to children. Because it would apply based on the date the asset was transferred, rather than the date the income was realized, ${ }^{191}$ an adult would no longer be able to give an appreciated asset to a child when she was, for example, thirteen years old, have her borrow against the asset, ${ }^{192}$ and then sell it as soon as she aged out of the kiddie tax. If she received the asset while subject to the kiddie tax, she would be taxable on the gain at her parents' rate, even if she waited to sell the asset until she was thirty years old. ${ }^{193}$ In addition, if she received an income-producing asset while subject to the kiddie tax, she would continue to be taxable on the income from that asset at her parents' tax rate, even after she aged out of the kiddie tax. The grown-up kiddie tax would effectively prevent any type of income shifting to children.

While the grown-up kiddie tax would encompass more types of income shifting over a broader timeframe, it would also reduce the distortions associated with the current kiddie tax. ${ }^{194}$ Under the grown-up kiddie tax, children would face no additional disincentive toward saving or investing. Moreover, they could save or invest for whatever future consumption they wanted; to avoid being taxed at their parents' rate, they would not be required to put their money in an individual retirement account, a 529 plan, or any other tax-advantaged savings vehicle that limited the use of funds. ${ }^{195}$ In fact, if a child were in one of the bottom two tax brackets, she would not owe any taxes on her investment

191. See supra note 127 and accompanying text.

192. Remember, by borrowing against the asset, a child could monetize the appreciation without paying any tax. See supra note 168 and accompanying text.

193. Again, this assumes that she is in a lower tax bracket than her parents. Like the current kiddie tax, as soon as her tax bracket is higher than her parents', she would be taxable at her rate.

194. See supra Part V.A.

195. See supra notes $152-60$ and accompanying text. 
returns. ${ }^{196}$ If she invested money she had earned, any return would be taxed to her at her own marginal rate.

The grown-up kiddie tax is more administrable than the original proposal for the kiddie tax would have been. Under the original proposal, children would have been required to keep track of who gave them assets. ${ }^{197}$ Although this is feasible, it would require record keeping that was not required for any other purpose. Under the grown-up kiddie tax, a child only has to keep track of assets that were received as gifts. Under current law, gifts are not included in a donee's gross income. ${ }^{198}$ However, to ensure that the donor's unrealized appreciation is taxed, the donee's basis in the assets carries over from the donor. ${ }^{199}$ For the donee to know how much tax will be due when she disposes of the asset, then, it is necessary for her to keep track of the carried-over basis. Thus, she needs to keep track of which of her assets were gifts; because all of her assets that were gifts will be subject to the kiddie tax, this record will also let her know which assets will be subject to the grown-up kiddie tax.

Because it is easier to keep track of what assets are gifts than it is to keep track of the identity of the donor, the grown-up kiddie tax will apply even where the income-producing asset is received as a gift from another child who is also subject to the kiddie tax. In this instance, the grown-up kiddie tax may be slightly overbroad, especially if the asset would not trigger the kiddie tax in the donor's hands, but the administrative ease makes up for the slight overbreadth. Moreover, it prevents an adult from laundering her income shifting by passing the asset through a child or string of children until it ultimately lands in the hands of the original donor's child.

\section{B. How the Grown-Up Kiddie Tax Prevents Abusive Planning}

The grown-up kiddie tax is not a perfect solution to the problem of income shifting, of course. As long as there is a progressive income tax, higher-earning taxpayers will have an incentive to shift a portion of their income to lower-earning taxpayers. ${ }^{200}$ And the grown-up kiddie tax does

196. See supra notes 129,134 and accompanying text.

197. See Thuronyi, supra note 7 , at 590 .

198. I.R.C. § 102(a) (2006).

199. See id. § 1015(a).

200. One solution to the problem of income shifting would be to replace the current progressive income tax with some type of flat tax. If all taxpayers were taxed at the same rate, there would be no tax savings by shifting income from a high-income taxpayer to a low-income taxpayer. See Joseph Bankman \& Thomas Griffith, Social Welfare and the Rate Structure: A New Look at Progressive 
nothing to prevent a high-income taxpayer from shifting income to a lower-income adult. ${ }^{201}$ In spite of the fact that it will not prevent $100 \%$ of abusive behaviors, the grown-up kiddie tax will prevent substantially all income shifting from adults to children.

The grown-up kiddie tax can be completely avoided by a donor giving cash to the child donee. In general, this is the correct result. The kiddie tax should prevent shifting income that would otherwise go to a higher-taxed adult. Cash does not produce an investment return unless and until it is invested; therefore, a gift of cash does not represent the shifting of unrealized appreciation or of future income that would otherwise be taxable to the donor.

In some cases, however, giving cash could be economically similar to giving an income-producing asset. This is easiest to see in the case where a parent owns a share of dividend-paying stock. Absent the kiddie tax, if she wanted to shift future income, she would give the stock to her child and the dividends would be taxed to the child at the child's rate. ${ }^{202}$ Under the grown-up kiddie tax, because the stock was a gift, dividends would be taxed at the parents' rate of tax until the child disposed of the stock. However, the parent could avoid the kiddie tax by selling the stock, giving the proceeds of the sale to her child, and having her child repurchase the same stock.

Causing the parent to sell the stock and give cash to her child would eliminate the shifting of unrealized appreciation - by selling the asset, she would realize and be taxable on the amount by which it had

Taxation, 75 CALIF. L. REV. 1905, 1930 (1987) (“The specific provisions governing gifts, trusts, family partnerships, loans at below-market rates of interest, unearned income of minor children, and divorce or separation agreements can be attributed largely to the progressive rate structure. All of these provisions could be simplified or eliminated by switching to a proportionate tax.”). However, even the most committed supporters of a flat tax do not advocate a "true flat-rate tax [that] would tax all income... [,] starting with the first dollar, at the same rate.” Barbara H. Fried, The Puzzling Case for Proportionate Taxation, 2 CHAP. L. REV. 157, 160-61 (1999). Instead, for political or fairness reasons, they support a "degressionary version of a progressive tax, in which the first $\mathrm{x}$ dollars of income...., sufficient to cover basic needs, is taxed at a zero rate, and all income... above that is taxed at the same positive rate.” Id. at 161.

201. Although this Article has focused on income shifting between adults and children, it is also possible to shift income between adults. This is especially possible between unmarried domestic partners and, in most cases, married same-sex couples. Addressing income shifting between adults could be accomplished by fundamentally rethinking the income tax treatment of gifts; such a rethinking, however, is beyond the scope of the kiddie tax and, as such, beyond the scope of this Article. It may be the subject of a future article.

202. The current kiddie tax would prevent this income shifting because the dividends would be taxable at her parents' rate. See supra Part III. However, because of its overbreadth, the current kiddie tax would also tax dividends on stock the child bought with money she earned at her parents' rate. See supra Part V.A. This overbreadth would be corrected under the grown-up kiddie tax. 
appreciated in value. ${ }^{203}$ Still, any future income on the asset would be taxed at the child's rate. Moreover, if the parent had an unrealized loss on the income-producing asset, she could, in essence, accelerate her loss while shifting future income.

To prevent these abuses, the grown-up kiddie tax would have to include a mechanism similar to the wash-sale rules. Under the wash-sale rules, any loss on the sale or other disposition of a security is disallowed if the seller of the security acquires, or contracts to acquire, a substantially similar security during the sixty-day period beginning thirty days before the disposition occurs. ${ }^{204}$ The wash-sale rules essentially prevent taxpayers from realizing losses without actually divesting themselves of the security; to use the tax loss, "taxpayers have to give up economic exposure to the depreciated asset (or double their exposure) for a specified period. The hope is that this friction is so unappealing that taxpayers choose, instead, to forgo the tax deduction."205

Under the grown-up kiddie tax, if any person sells an asset, gives a gift to a child, and the child acquires a substantially similar asset within the sixty-day window described in the wash-sale rules, the asset will be deemed a gift and will be subject to the kiddie tax. Moreover, recognizing that gifts may be more difficult to detect within a family, the wash-sale-style rule would be stricter when dealing with parents. Under the grown-up kiddie tax, if a parent sells an asset and her child acquires a substantially similar asset within the same sixty-day window described in the wash-sale rules, the asset will be deemed a gift from the parent to the child and will be subject to the grown-up kiddie tax, even if the parent does not make a gift to the child.

In addition to treating the asset as a gift and, therefore, taxing income from the asset at the child's parents' rate, the grown-up kiddie tax will disallow any loss to the donor or deemed donor. By doing so, the grownup kiddie tax will prevent donors from harvesting losses while maintaining indirect economic exposure to the asset. ${ }^{206}$ The kiddie tax would not, however, disallow gains. While this means gains and losses are treated differently, accelerating gains is not abusive, and, as such, the government does not need to prevent the recognition of gains to protect the tax base. ${ }^{207}$

\footnotetext{
203. See I.R.C. § 1001(a).

204. See id. § 1091(a).

205. David M. Schizer, Scrubbing the Wash Sale Rules, J. TAX’N FIN. Products, Fall 2003, at

206. See id. at 69.

207. See id. ("It is well understood that [accelerating losses], if unconstrained, causes dramatic
} $67,70$. 
In addition, the grown-up kiddie tax should include an anti-abuse provision that provides the IRS with the flexibility to address transactions structured to avoid the kiddie tax. Such administrative flexibility could be used, for example, to recast the sale of an asset to a child by a related person at a below-market price as a gift where it appears that the purpose of the sale was to avoid the application of the kiddie tax. $^{208}$

\section{VIII.CONCLUSION}

The kiddie tax, originally passed almost a quarter century ago to prevent the perceived problem of parents shifting income-producing assets to their children, has been largely ignored by academics in the intervening years. When it has been considered, analysis of the kiddie tax has generally been limited to discussing how it functions and how parents and children can adjust their investment and savings strategies to avoid the complexity and punitive nature of the kiddie tax.

The kiddie tax should not be ignored, though. It stands as one of the tax law's main defenses against tax avoidance. In its current form, it affects more than 300,000 children and raises hundreds of millions of dollars in revenue for the government. ${ }^{209}$ As tax rates increase, however, the kiddie tax is less capable of preventing the income shifting against which Congress intended it to stand. While it adds complexity to a child's determination of her tax liability, the kiddie tax is limited in its ability to prevent tax-motivated income shifting. Although it makes gifts to children of income-producing property less attractive, it permits the unchecked transfer of appreciated assets to children while, at the same time, distorting children's incentives to save and invest vis-à-vis their incentives to spend their money immediately.

As such, the kiddie tax needs to grow up. The version of the kiddie tax proposed in this Article would more effectively combat wealthy taxpayers' shifting of income to children. And it would eliminate distortions that children face in deciding what to do with their money, whether they earned it at a job or received it as a gift.

declines in government revenue.”).

208. This type of broad anti-abuse power would be similar to the anti-abuse provisions applicable to subchapter K. According to the Treasury regulations, "even though the transaction may fall within the literal words of a particular statutory or regulatory provision, the Commissioner can determine, based on the particular facts and circumstances, that to achieve tax results that are consistent with the intent of subchapter K," the IRS can disregard the form of the transaction. Treas. Reg. § 1.701-2(b) (as amended in 1995).

209. See supra notes 55-56 and accompanying text. 
Even the grown-up kiddie tax is not enough to entirely prevent taxpayers from shifting income. Ultimately, the best any version of a kiddie tax can do is to prevent taxpayers from shifting their income to children; it does nothing to prevent high-income taxpayers from shifting their income to lower-income adults. To fully eliminate income shifting would require a fundamental change to the Internal Revenue Code, and it is not clear that, in the present political climate, Congress has the will to make such a fundamental change to the tax law. ${ }^{210}$ But the grown-up kiddie tax can serve as an important protection against income shifting until Congress has the political will to pass broader fundamental reform.

210. Currently, Congress seems incapable of accomplishing even the nonfundamental changes to the tax law that it needs to make. For example, it could not prevent the estate tax from lapsing in 2009, despite an almost universal consensus that it needed to do so. See, e.g., Jonathan G. Blattmachr et al., The Impossible Has Happened: No Federal Estate Tax, No GST Tax, and Carryover Basis for 2010, 112 J. TAX’N 68, 68 (2010) (“Although the Code has provided that there would be no estate or GST tax for 2010 since the passage of EGTRRA, few thought it could happen.”); Robert D. Hershey, Jr., Waiting on Washington, N.Y. TIMES, Feb. 14, 2010, at BU9 (“'I don't think there's anything more significant than the estate tax,' said Catharine V. Fairley, a tax planner and partner at Draper \& McGinley in Frederick, Md., citing its wide implications for wills, gifts and trusts. 'No one saw this coming-that they let the estate tax sunset.'”). And a year later, on the eve of the expiration of the Bush tax cuts, Congress was again paralyzed, in spite of the fact that Republicans wanted to make the cuts permanent and Democrats wanted to maintain the cuts for lower-income Americans. See, e.g., David M. Herszenhorn, Next Big Battle in Washington: Bush's Tax Cuts, N.Y. Times, July 25, 2010, at A1 ("Given the partisan gridlock of recent months, there is a chance that the battle could go down to the last minute, or even - in the face of a stalemate- that the tax cuts could be allowed to expire completely, a development that Republicans are already heralding ominously as the largest tax increase in history and that lawmakers in both parties say could be the worst outcome.”); David M. Herszenhorn, Republicans Threaten to Bring Senate to Halt over Tax Dispute, N.Y. TimeS, Dec. 2, 2010, at A24 ("[R]enewed partisan fury engulfed the Senate on Wednesday, as Republicans threatened to block any legislation until a deal is reached to extend the expiring Bush-era tax cuts, potentially derailing the Democrats' busy end-of-year agenda.”); John D. McKinnon, Bush-Era Tax Cuts a Likely Campaign Theme, WALL ST. J., July 26, 2010, at A2 ("Democrats are aiming to push legislation extending Bush-era middle-class tax cuts ahead of midterm elections. But with Republicans and several Democrats advocating a similar extension for high-earners, too, prospects for passage before November balloting appear uncertain.”); Lori Montgomery, Battle Looms on Tax Breaks; Bush-Era Cuts for Rich at Issue Democrats See a Chance to Put GOP on the Spot, WASH. Post, July 25, 2010, at A1 ("Given the competing political pressures, it is not clear that Democrats can push anything through Congress before they have to face voters. Even if Baucus wins approval of a tax-cut extension in committee, Senate Majority Leader Harry M. Reid (D-Nev.) has yet to decide whether to bring it before the full Senate."). 